\title{
PENGARUH TEKNIK MENYIKAT GIGI VERTIKAL TERHADAP TERJADINYA RESESI GINGIVA
}

\author{
${ }^{1}$ Joan Christiany \\ ${ }^{2}$ Vonny N.S Wowor \\ ${ }^{2}$ Christy N. Mintjelungan
}

\author{
${ }^{1}$ Kandidat Skripsi Program Studi Pendidikan Dokter Gigi Fakultas Kedokteran \\ ${ }^{2}$ Program Studi Pendidikan Dokter Gigi Fakultas Kedokteran \\ Universitas Sam Ratulangi Manado \\ Email: joan.chrisiany@yahoo.com
}

\begin{abstract}
Gingival recession is a state or condition of the marginal gingiva that is more apical than the cementoenamel junction and is usually accompanied by opening of the root surface of teeth. Wrong brushing technique is the most common cause of gingival recession. Brushing technique that is most widely used is vertical direction. This study aimed to determine the influence of vertical brushing technique to the occurrence of gingival recession in students of Dentistry study program Sam Ratulangi University. This was a descriptive analytical study with a cross sectional design. Samples were obtained by using the purposive sampling method. Data of brushing technique were obtained by observing the vertical movement of tooth brushing used by respondents and were filled in a check list. Gingival recession was obtained by examination of the oral cavity and the severity of gingival recession was determined. There were 71 students as samples. Data were analyzed with the chi-square test. The results showed the influence of vertical brushing technique to gingival recession with a $\mathrm{p}$ value $=0.000(\mathrm{p}=$ $<0.005)$.
\end{abstract}

Keywords: gingival recession, vertical techniques, brushing technique

\begin{abstract}
Abstrak: Resesi gingiva adalah kondisi marginal gingiva yang lebih ke apikal dari Cemento Enamel Junction dan biasanya disertai dengan terbukanya permukaan akar gigi. Kesalahan dalam menyikat gigi merupakan penyebab resesi gingiva yang paling umum. Kesalahan yang dimaksud yaitu kesalahan dalam teknik menyikat gigi. Teknik menyikat gigi yang paling banyak di gunakan ialah teknik menyikat gigi vertikal. Penelitian ini bertujuan untuk mengetahui berapa besar pengaruh teknik menyikat gigi vertikal terhadap terjadinya resesi gingiva pada mahasiswa Program Studi Pendidikan Dokter Gigi Universitas Sam Ratulangi. Penelitian ini menggunakan metode deskriptif analitik dengan rancangan potong lintang. Pengambilan sampel dilakukan dengan metode purposive sampling. Pengambilan data teknik menyikat gigi vertikal dengan cara melihat gerakan menyikat gigi yang digunakan subjek penelitian. Hasil pengamatan dimasukkan pada check list sesuai dengan teknik menyikat gigi yang digunakan. Resesi gingiva didapat dengan melakukan pemeriksaan rongga mulut kemudian dihitung tingkat keparahan resesi gingiva. Jumlah sampel dalam penelitian ini sebanyak 71 mahasiswa. Analisis data dilakukan dengan menggunakan uji chi-square. Hasil data menunjukkan adanya pengaruh teknik menyikat gigi vertikal terhadap resesi gingiva dengan nilai $\mathrm{p}=0,000(\mathrm{p}=<0,005)$.
\end{abstract}

Kata kunci: resesi gingiva, teknik vertikal, teknik menyikat gigi

Kesehatan gigi dan mulut merupakan bagian yang tidak dapat dipisahkan dari kesehatan umum . Terganggunya kesehatan gigi dan mulut akibat kebersihan gigi dan 
mulut yang kurang terpelihara dapat mengganggu fungsi bicara, pengunyahan, rasa percaya diri individu serta kesehatan secara umum sehingga dapat memengaruhi kualitas hidup. ${ }^{1}$

Saat ini kesehatan gigi dan mulut masih menjadi masalah di Indonesia termasuk di Provinsi Sulawesi Utara. Hal ini dapat dilihat dari data Riset Kesehatan Dasar (RISKESDAS) 2013 yang menunjukkan bahwa prevalensi penduduk yang memiliki masalah kesehatan gigi dan mulut di Indonesia sebesar $25,9 \%$ atau meningkat 2,5\% dari angka 23,4\% di tahun 2007. Provinsi Sulawesi Utara berada pada urutan ke empat dari provinsi yang masih memiliki masalah kesehatan gigi dan mulut, dengan angka sebesar $31,6 \%{ }^{2}$

Penyakit periodontal merupakan salah satu penyakit yang sering terjadi pada penduduk Indonesia. hal ini dapat dilihat dari data Riset Kesehatan Dasar (RISKESDAS) 2013 yang menunjukkan bahwa prevalensi penduduk yang memiliki masalah penyakit periodontal di Indonesia sebesar 96,58\%. Data ini memperlihatkan bahwa gangguan atau penyakit pada jaringan penyangga atau jaringan periodontal merupakan salah satu masalah utama bagi kesehatan gigi dan mulut masyarakat. $^{3}$

Gigi dan mulut yang kebersihannya terjaga merupakan salah satu faktor yang mendukung terciptanya gigi dan mulut yang sehat, termasuk jaringan periodontal. Penggunaan sikat gigi sangat penting dalam menunjang kesehatan gigi dan mulut, namun di sisi lainnya penggunaan sikat gigi bisa memberikan dampak kurang baik bagi kesehatan gigi apabila digunakan dengan cara yang kurang tepat. ${ }^{4}$

Keberhasilan pemeliharaan kebersihan gigi lewat tindakan menyikat gigi dipengaruhi oleh teknik atau cara menyikat gigi yang tepat. Teknik menyikat gigi yang sering digunakan tidak tepat ialah teknik menyikat gigi vertikal dan horizontal. Jika teknik menyikat gigi ini dilakukan dengan cara yang kurang tepat dapat menyebabkan tersingkapnya akar gigi akibat berpindahnya ikatan margin gingiva ke posisi apikal dari cementoenamel junction, yang disebut sebagai resesi gingiva. ${ }^{4,5}$ Resesi gingiva dapat menyebabkan berbagai masalah seperti keluhan rasa ngilu, estetik terganggu, serta risiko terjadinya karies pada permukaan akar gigi. ${ }^{4}$

Third National Health and Nutrition Examination Survey di Amerika menemukan bahwa prevalensi resesi gingiva meningkat seiring bertambahnya usia, dimana $0,5 \%$ pada usia $18-24$ tahun mempunyai resesi gingiva parah $(>3 \mathrm{~mm})$, meningkat menjadi $45 \%$ pada usia diatas 65 tahun. Resesi gingiva dapat terjadi secara fisiologis dan patologis, dan resesi gingiva secara patologis umumnya disebabkan oleh kesalahan penyikatan gigi. ${ }^{4}$

Resesi gingiva secara patologis dapat mengenai golongan dewasa muda. Dari hasil penelitian yang dilakukan di India dan Brazil menunjukkan golongan umur 15-24 tahun didapatkan $86,16 \%$ memiliki resesi gingiva kurang dari $3 \mathrm{~mm}$ dan 11,83\% memiliki resesi gingiva 3-4 $\mathrm{mm}^{5}$

Data hasil penelitian tentang gambaran resesi gingiva ditinjau dari metode menyikat gigi yang diteliti oleh Subadi pada Mahasiswa Program Studi Kedokteran Gigi Universitas Sam Ratulangi di tahun 2012, terdapat 95,5\% mengalami resesi gingiva pada 2 regio dan 4 regio yaitu 2 regio anterior dan 4 regio posterior. Hal ini terjadi karena ditemukan sebagian besar mahasiswa masih menggunakan teknik menyikat gigi secara vertikal. Dari data hasil penelitian ini ditemukan 60\% mahasiswa menggunakan teknik vertikal. Oleh sebab itu penulis tertarik melanjutkan penelitian mengenai pengaruh teknik menyikat gigi vertikal terhadap terjadinya resesi gingiva pada Mahasiswa Program Studi Pendidikan Dokter Gigi Universitas Sam Ratulangi. ${ }^{5}$

\section{BAHAN DAN METODE PENELITIAN}

Jenis penelitian ini deskriptif analitik dengan pendekatan potong lintang. Penelitian ini dilakukan di Program Studi Pendidikan Dokter Gigi Universitas Sam Ratulangi Manado, pada bulan Juni - 
September 2015.

Populasi penelitian ini ialah mahasiswa Program Studi Pendidikan Dokter Gigi Universitas Sam Ratulangi berjumlah 249 mahasiswa. Kriteria inklusi pada penelitian ini yaitu bersedia sebagai subjek penelitian, dibuktikan dengan informed concent, terdaftar sebagai mahasiswa Angkatan 2011-2014 yang aktif kuliah, bersifat kooperatif selama pengambilan data dan hadir pada saat penelitian berlangsung. Jumlah Sampel penelitian sebanyak 71 sampel. Teknik pengambilan sampel menggunakan metode total sampling.

Sebelum melakukan penelitian peneliti menjelaskan tujuan penelitian kepada calon responden yang akan menjadi sampel dan ditanyakan kesediaannya untuk terlibat dalam penelitian sebagai sampel. Kesediaan calon responden dibuktikan dengan penandatanganan informed concent.

Data primer berupa data mengenai teknik menyikat gigi dan resesi gingiva serta data karakteristik jenis kelamin responden diperoleh melalui tanya jawab dan pemeriksaan langsung di rongga mulut responden.

Tingkat keparahan resesi gingiva diukur dengan teknik pengukuran menggunakan probe periodontal. Pengukuran dilakukan dengan menghitung kedalaman resesi atau Recession Depth (RD), yaitu jarak dari margin gingiva ke cementoenamel junction dalam satuan milimeter. Hasil pengukuran didapat dari jumlah skor dibagi jumlah gigi yang diperiksa Tingkat keparahan resesi gingiva ditentukan berdasarkan indeks resesi yaitu slight recession (resesi gingiva kurang dari $3 \mathrm{~mm}$ ) menggunakan skor 4; moderate recession (resesi gingiva antara 3-4 mm) menggunakan skor 5; dan extensive recession (resesi gingiva lebih dari $4 \mathrm{~mm}$ ) menggunakan skor 6. Gigi yang diperiksa dalam pengukuran diwakili oleh gigi: $^{6}$ Insisivus pertama rahang atas (RA) regio kanan (11), Molar pertama rahang atas (RA) regio kanan (16), Molar pertama rahang atas (RA) regio kiri (26), Insisivus pertama rahang bawah (RB) regio kiri (31), Molar pertama rahang bawah (RB) regio kiri (36), dan Molar pertama rahang bawah (RB) regio kanan (46). Instrumen yang digunakan pada penelitian ini, yaitu lembar informed concent, lembar check list teknik menyikat gigi, dan lembar pemeriksaan indeks resesi gingiva.

Data hasil penelitian diolah dalam bentuk frekuensi dan distribusi dengan menggunakan program komputer kemudian dianalisis menggunakan analisis univariat untuk menggambarkan secara tunggal variabel-variabel penelitian baik dependen maupun idependen dalam bentuk distribusi frekuensi dan dihitung persentasinya dan analisis bivariat untuk melihat pengaruh teknik menyikat gigi vertikal terhadap resesi gingiva menggunakan uji chi-square.

\section{HASIL PENELITIAN DAN BAHASAN}

Penelitian dilakukan di kampus Program Studi Pendidikan Dokter Gigi Fakultas Kedokteran Universitas Sam Ratulangi Manado, yang merupakan salah satu Program Studi di bawah naungan Fakultas Kedokteran. Program Studi Pendidikan Dokter Gigi beralamat di Jln. Kampus Unsrat Kleak Manado Sulawesi Utara. Populasi penelitian ialah mahasiswa Program Studi Pendidikan Dokter Gigi Universitas Sam Ratulangi angkatan 20112014 yang berjumlah 249 .

Jumlah subjek dalam penelitian ini yaitu 71 subjek, terdiri dari 25 subjek (35,2\%) berjenis kelamin laki-laki dan 46 subjek (64,7\%) berjenis kelamin perempuan (Tabel 1).

Tabel 1. Distribusi subjek penelitian berdasarkan jenis kelamin

\begin{tabular}{ccc}
\hline Jenis & (n) & $(\%)$ \\
Kelamin & & 35,2 \\
\hline Laki-laki & 25 & 64,8 \\
Perempuan & 46 & 100 \\
Total & 71 & \\
\hline
\end{tabular}

Tabel 2 menunjukkan subjek penelitian yang terkena resesi gingiva pada bagian anterior rahang atas sebanyak 37 responden (52,11\%), pada posterior rahang atas kanan mengalami resesi gingiva sebanyak 65 
Christiany, Wowor, Mintjelungan: Pengaruh teknik menyikat...

responden (91,5\%) dan pada bagian posterior rahang atas kiri, mengalami sebanyak 64 responden $(90,1 \%)$.

Tabel 2. Distribusi resesi gingiva berdasarkan bagian yang terkena resesi gingiva pada rahang atas

\begin{tabular}{lcc}
\hline \multirow{2}{*}{ Rahang Atas } & \multicolumn{2}{c}{ Resesi Gingiva } \\
\cline { 2 - 3 } & $\mathrm{n}$ & $\%$ \\
\hline Anterior & 37 & 52,11 \\
Posterior kanan & 65 & 91,5 \\
Posterior kiri & 64 & 90,1 \\
\hline
\end{tabular}

Tabel 3 menunjukkan subjek penelitian yang terkena resesi gingiva pada bagian anterior rahang bawah sebanyak 39 responden (54,9\%), pada bagian posterior rahang bawah kanan sebanyak 68 responden (95,7\%), dan pada bagian posterior rahang bawah kiri sebanyak 67 orang $(94,3 \%)$.

Tabel 3. Distribusi resesi gingiva berdasarkan bagian yang terkena resesi gingiva pada rahang bawah

\begin{tabular}{lcc}
\hline \multirow{2}{*}{ Rahang Bawah } & \multicolumn{2}{c}{ Resesi Gingiva } \\
\cline { 2 - 3 } \multicolumn{1}{c}{ Anterior } & 39 & $\%$ \\
\hline Posterior kanan & 68 & 94,9 \\
Posterior kiri & 67 & 94,7 \\
\hline
\end{tabular}

Tabel 4 menunjukkan subjek penelitian yang menggunakan teknik menyikat gigi vertikal murni dua arah sebanyak 66 responden (92,9\%) dan teknik menyikat gigi vertikal sebanyak 5 orang (7,10\%).

Tabel 4. Distribusi subjek penelitian berdasarkan teknik menyikat gigi vertikal.

\begin{tabular}{lcc}
\hline Teknik Menyikat Gigi & $\mathrm{n}$ & $\%$ \\
\hline Vertikal dua arah & 66 & 92,9 \\
Vertikal satu arah & 0 & 0 \\
Vertikal kombinasi & 5 & 7,10 \\
$\quad$ Total & 71 & 100 \\
\hline
\end{tabular}

Tabel 5 menunjukkan subjek penelitian yang mengalami resesi gingiva ringan atau slight sebanyak 57 responden (86,3\%), dan resesi gingiva sedang atau moderate sebanyak 14 reponden (19,7\%).

Tabel 5. Distribusi subjek penelitian berdasarkan tingkat keparahan resesi gingiva

\begin{tabular}{lcc}
\hline Resesi Gingiva & $\mathrm{n}$ & $\%$ \\
\hline Slight & 57 & 86,3 \\
Moderate & 14 & 19,7 \\
Extensive & 0 & 0 \\
\hline Total & 71 & 100 \\
\hline
\end{tabular}

Dari hasil analisis data diperoleh nilai $\mathrm{p}=0,000<\mathrm{p}=0,005$ menunjukkan bahwa pengaruh teknik vertikal terhadap resesi gingiva bermakna.

Tabel 6. Analisis data menggunakan uji chisquare.

\begin{tabular}{llccccc}
\hline & \multicolumn{4}{c}{ Resesi Gingiva } & \\
\cline { 3 - 5 } & & \multicolumn{3}{c}{ Slight } & \multicolumn{3}{c}{ Moderate } & \multirow{2}{*}{$\mathrm{P}$} \\
\cline { 3 - 5 } & $\mathrm{N}$ & $\%$ & $\mathrm{n}$ & $\%$ & \\
\hline \multirow{2}{*}{$\begin{array}{l}\text { Resesi } \\
\text { gingiva }\end{array}$} & Murni & 57 & 86,3 & 9 & 13,7 & \multirow{2}{*}{0,000} \\
& Kombinasi & 0 & 0 & 5 & 100 & \\
\hline Total & & 57 & 80,2 & 14 & 19,8 & \\
\hline
\end{tabular}

Hasil penelitian menunjukkan subjek penelitian dengan jenis kelamin perempuan merupakan jumlah terbanyak 46 orang (64,7\%). Jumlah ini dua kali lipat lebih banyak dari pada sampel laki-laki yang hanya berjumlah 25 orang (35,2\%). Hal ini disebabkan karena subjek penelitian berjenis kelamin perempuan cenderung lebih memperhatikan penampilan dan mempertahankan nilai estetik sehingga perempuan memiliki keinginan lebih besar untuk memelihara kesehatan gigi dan mulut. Hasil penelitian Hamamci dan Svedström-Oristo tahun 2009 menyatakan bahwa pria biasanya lebih puas dengan estetik gigi mereka dibanding wanita. Penelitian ini juga didukung oleh penelitian Aditya di Makasar dimana dari 60 subjek penelitian sebagian besar yang berjenis kelamin perempuan mengalami resesi gingiva dua kali lipat lebih besar $(66,7 \%)$ daripada laki-laki (33,3\%). ${ }^{8}$

Hasil penelitian berdasarkan jenis kelamin menunjukkan seluruh subjek penelitian (100\%) baik subjek penelitian 
berjenis kelamin laki-laki maupun yang berjenis kelamin perempuan mengalami resesi gingiva (Tabel 1). Hal ini dikarenakan sebagian besar mahasiswa Pendidikan Dokter Gigi memiliki kebiasaan menyikat gigi dengan teknik menyikat gigi vertikal murni dua arah. Hasil penelitian ini didukung oleh Beltran pada tahun 2013 di Chili Amerika Selatan, dimana dari 105 subjek penelitian seluruhnya mengalami resesi gingiva. $^{9}$ Hasil ini juga didukung oleh penelitian Chrysanthakopaulos pada tahun 2010 di Yunani, dimana dari 344 subjek penelitian seluruhnya mengalami resesi gingiva. ${ }^{10}$

Hasil penelitian berdasarkan rahang atas menunjukan yang paling banyak mengalami resesi gingiva yaitu posterior rahang atas kanan (91,5\%) (Tabel 2) dan pada rahang bawah yang paling banyak pada bagian posterior rahang bawah kanan (95,7\%) (Tabel 3). Hal ini disebabkan karena subjek penelitian saat menyikat gigi menggunakan tangan kanan sehingga tekanan menyikat gigi pada bagian kanan lebih besar dibandingkan bagian kiri dan hal ini juga disebabkan karena saat menggunakan tangan kanan bagian rahang sebelah kiri lebih sulit terjangkau hal ini menyebabkan bagian posterior rahang bawah kanan lebih banyak mengalami resesi gingiva. Hasil penelitian ini didukung oleh penelitian yang dilakukan oleh Subadi pada tahun 2012 menunjukan bahwa regio yang paling banyak terkena resesi gingiva yaitu regio posterior rahang bawah kanan (67\%). ${ }^{11}$

Hasil penelitian berdasarkan teknik menyikat gigi vertikal paling banyak digunakan oleh subjek penelitian untuk menyikat gigi ialah teknik menyikat gigi vertikal dengan dua arah (92,9\%) (Tabel 4). Hal ini dikarenakan teknik menyikat gigi vertikal dua arah sangat mudah digunakan, mudah dikuasai tanpa harus memerlukan latihan khusus dan tidak memakan waktu yang lama. Dalam penelitian ini tidak ditemukan subjek yang menggunakan teknik menyikat gigi vertikal satu arah dan teknik menyikat gigi vertikal modifikasi stilman hal ini dikarenakan teknik menyikat gigi vertikal satu arah dan modifikasi stilman merupakan teknik yang sulit dilakukan dan memerlukan latihan. ${ }^{12}$

Hasil penelitian yang menggunakan teknik menyikat gigi vertikal murni dua arah sebagian besar (86,3\%) memiliki keparahan resesi gingiva ringan atau slight dan seluruh subjek penelitian (100\%) yang menggunakan teknik menyikat gigi vertikal kombinasi mengalami resesi gingiva sedang atau moderate. Hal ini mungkin disebabkan karena teknik menyikat gigi vertikal murni dua arah hanya melakukan gerakan satu sisi saja sehingga resesi gingiva tidak begitu luas sedangkan teknik menyikat gigi vertikal kombinasi melakukan gerakan melebar dan semua sisi bagian servikal gigi terkena dan hal ini membuat keparahan resesi gingiva lebih meluas dibandingkan saat menggunakan teknik menyikat gigi vertikal murni dua arah. Hal ini didukung penelitian sebelumnya yang menyatakan bahwa teknik menyikat gigi vertikal merupakan salah satu penyebab terjadinya resesi gingiva. Penelitian yang dilakukan Dowdad di India dan Beltran di Amerika Selatan mendapatkan hasil bahwa teknik menyikat gigi vertikal dapat menyebabkan cedera pada jaringan lunak yang menyebabkan resesi gingiva. Hasil penelitian ini juga didukung oleh Subadi yang mendapatkan hasil sebagian besar subjek penelitian yang menggunakan teknik vertikal baik anterior maupun posterior mengalami resesi gingiva pada dua sampai empat regio. ${ }^{5}$

Hasil penelitian menunjukkan sebagian besar $(86,3 \%)$ mengalami resesi gingiva kurang dari $3 \mathrm{~mm}$ atau slight recession dan $(19,7 \%)$ mengalami resesi gingiva dengan tingkat keparahan 3-4 mm atau moderate recession. Hal ini disebabkan karena jumlah mahasiswa yang menggunakan teknik menyikat gigi vertikal murni dua arah lebih banyak ditemukan pada mahasiswa Program Studi Pendidikan Dokter Gigi dari pada teknik vertikal kombinasi sehingga menghasilkan tingkat keparahan resesi gingiva yang ringan atau slight lebih banyak dari pada tingkat keparahan resesi gingiva sedang atau 
moderate. Hasil penelitian ini sama dengan hasil penelitian yang dilakukan oleh Dowdad di India pada tahun 2001 dimana sebagian besar $(86,16 \%)$ mengalami slight recession, dan (11,83\%) mengalami moderate recession. ${ }^{11}$ Berbeda dengan penelitian yang dilakukan oleh Beltran pada tahun 2013 di Amerika Utara yang menggunakan subjek penelitian dengan umur diatas 50 tahun sebagian besar mengalami extensive recession atau lebih dari $4 \mathrm{~mm} .{ }^{9}$ Hal ini menunjukkan bahwa usia diatas 50 tahun memiliki resiko resesi gingiva lebih parah. Prevalensi, luas, dan keparahan resesi gingiva meningkat seiring bertambahnya usia. ${ }^{13}$ Dalam penelitian ini sebagian besar mengalami slight recession atau kurang dari $3 \mathrm{~mm}$ didukung dengan faktor usia pada penelitian ini 21-22 tahun.

Hasil uji secara statistik menunjukan terdapat pengaruh teknik menyikat gigi vertikal terhadap resesi gingiva dapat dilihat dari hasil analisis bivariat dengan uji chi-square menggunakan program statistical package for the social science (SPSS) dari hasil analisis data diperoleh nilai $\mathrm{p}=0,000(\mathrm{p} \leq 0,005)$ menunjukkan adanya pengaruh teknik menyikat gigi vertikal terhadap terjadinya resesi gingiva.

\section{SIMPULAN}

Berdasarkan hasil penelitian di Program Studi Pendidikan Dokter Gigi dapat disimpulkan bahwa terdapat pengaruh teknik menyikat gigi vertikal terhadap terhadap terjadinya resesi gingiva.

\section{SARAN}

1. Masyarakat pada umunya lebih khusus lagi mahasiswa Program Studi Pendidikan Dokter Gigi Universitas Sam Ratulangi, diharapkan dapat memilih teknik menyikat gigi yang menstilmusikan gingiva seperti rolling strokes dan modifikasi stilman

2. perlu dilakukan penelitian lanjutan untuk menliti hubungan durasi, frekuensi, dan kekuatan dari menyikat gigi terhadap resesi gingiva.

\section{DAFTAR PUSTAKA}

1. Wuse C, Tahulending AA. Cara menyikat gigi dan terjadinya resesi gingiva. Jurnal IK. 2013;8(1):60-4.

2. Riset Kesehatan Dasar (RISKESDAS). Badan penelitian dan pengembangan kesehatan kementrian kesehatan RI, 2013; p. 111-12.

3. Sasea A, Lampus BS. Gambaran status kebersihan rongga mulut dan status gingiva pada mahasiswa dengan gigi berjejal. E-gigi. 2013;1(1):53.

4. Sunnati, Hakim FR, Nurlita F. Hubungan antara teknik menyikat gigi dengan resesi gingiva. Dent J. 2011;3(2): 332-9.

5. Subadi IW. Gambaran resesi gingiva ditinjau dari metode menyikat gigi pada mahasiswa kedokteran gigi. Dentire Journal. 2013;2(1):6-9.

6. Rahayu S. Peningkatan kedalaman cllinical attachment loss gingiva antara pengguna tusuk gigi berbahan bambu dengan yang bukan pengguna [Skripsi]. Denpasar: Universitas Mahasaraswati Fakultas Kedokteran Gigi; 2014.

7. Hammaci N, Basaran G, Uysal E. Dental aesthetic index scores and perception of personal dental appearance among Turkish University students. Eur J Orthod. 2009;31(2):168-73.

8. Asmar HA. Perbedaan tingkat keparahan resesi gingiva masyarakat dataran tinggi dan masyarakat dataran rendah [Skripsi]. Universitas Hasanuddin 2014.

9. Beltran V, Wilckens M, Cantin M. Effect of manual toothbrushing on gingival recession in an adult population sample in south of Chile. J. Odontostomat. 2014;8(3):461-7

10.Chrysanthakopulos NA. Aetiology and severity of gingival recession in an adult population sample in Greece. Dent Res J. 2011;8(2):64-70

11.Dowdad V. Etiology and severity of gingival recession among young individuals inbelgaum district in India. [serial online] [cited 2012 May 04]. Available from: URL: http://ejum.fsktm.um.edu.my/article/4 21.pdf

12.Putri HM, Herijulianti E, Nurjannah N. Ilmu pencegahan penyakit jaringan 
Jurnal e-GiGi (eG), Volume 3, Nomor 2, Juli-Desember 2015

keras dan jaringan pendukung gigi.

Jakarta: EGC, 2010.

13.Fiorellini JP, Kim DM, Ishikawa SO.

Clinical Features of Gingivitis. In:

Newman MG, Takei HH, Klokkevold
PR, Carranza FA, editors. Carranza's Clinical Periodontology (10th ed). Philadelphia: Saunders, 2006: p. 36272. 